\title{
Experimental Unit Status Date
}

National Cancer Institute

\section{Source}

National Cancer Institute. Experimental Unit Status Date. NCI Thesaurus. Code C93836.

The date (and time) on which the status is assigned to the experimental unit. 